\title{
Raster-based Model for Mass Movement in Malang Regency, East Java, Indonesia.
}

\author{
Sandy Budi Wibowo ${ }^{1, *}$, Franck Lavigne ${ }^{2}$, Siddiq Luqman Rifai ${ }^{3}$, Rani Rahim Suryandari ${ }^{3}$, Idea \\ Wening Nurani ${ }^{4}$, St. Dwi Ermawan Danas Putra ${ }^{5}$, Wahyu Widi Pamungkas ${ }^{5}$ \\ ${ }^{1}$ Department of Geographic Information Science, Faculty of Geography, Universitas Gadjah Mada, Yogyakarta, Indonesia. \\ ${ }^{2}$ Institute de Géographie, Université Paris 1 Panthéon-Sorbonne, Paris, France. \\ ${ }^{3}$ Cartography and Remote Sensing Study Program, Faculty of Geography, Universitas Gadjah Mada, Yogyakarta, Indonesia \\ ${ }^{4}$ Department of Development Geography, Faculty of Geography, Universitas Gadjah Mada, Yogyakarta, Indonesia. \\ ${ }^{5}$ Laboratory of Geographic Information System, Faculty of Geography, Universitas Gadjah Mada, Yogyakarta, Indonesia.
}

* Corresponding author : sandy_budi_wibowo@ugm.ac.id

Tel.:+62-274-6492334; fax: +62-274-589595

Received: Mar 31, 2020.; Accepted: Sept 18, 2020

DOI 10.25299/jgeet.2020.5.4.4737

\begin{abstract}
Strengthening geospatial technology is very important in order to support disaster mitigation strategy, to manage vulnerable communities and to protectcritical environments. The main challenge in identifying disaster characteristics such as mass movements is the lack of direct observation during the event because it is too dangerous for researchers. Geo-Information Technology as a product of Geographic Information Science can be used as a solution in order to model the characteristics of mass movements. The purpose of this study is focused on identifying landslide processes from point of view of raster-based model. The method of this research emphasizes dynamic landslide model derived from time series raster calculation using MassMov2D algorithm. The geographic database that was built for spatial modeling comes from pedogeomorphological and Remote Sensing survey outputs, especially topographic data, landforms and soil physical properties. The result shows that the relationship between pixels (neighborhood) is determined by the topology of the energy gradient line direction which allows to transfer the value between each pixel. The movement of landslide material starts from the toe. This decreases the stability of the landslide material in the main body of the landslide and generate progressive erosion. The raster-based model can finally reconstruct and identify the stages of initiation, transport and deposition landslide material.
\end{abstract}

Keywords: Geo-Information Technology, raster-based models, landslides, mass movements

\section{Introduction}

Raster-based model is part of Geo-Information Technology that can be applied for disaster studies, especially mass movements. It allows researchers to identify and reconstruct the process of mass movements, such as debris flows and landslides. This is very important because usually the identification of mass movement process is very limited. Such identification is pretty dangerous to be done directly in the field during the event.

The need for reconstruction and identification of mass movement processes becomes urgent and critical to minimize the number of victims which are often reported by mass media during the rainy season. Therefore, strengthening geospatial technology for disaster studies is paramount, especially for supporting disaster mitigation strategy, for managing vulnerable communities and for protecting critical environments.

Various mass movement modeling techniques have been developed such as Machine Learning Model (Bui et al., 2020), Deep Learning Neural Network (Dao et al., 2020), Cellular Automata (Adamska-Szatko and Bała, 2010), Statistical approaches (He et al., 2019) Physical Simulation (Wibowo, 2011; Wibowo, 2016, Ran et al., 2018; Weidner et al., 2019; Marin and Velásquez, 2020) and Vibration Simulation (Katz et Aharonov, 2006; Chen et al. 2020).

Numerical model (raster) based on physical characteristics of materials is being developed as well such as DAN and DAN $3 \mathrm{D}$ based on the application of quantum mechanics to estimate the average depth of material of mass movements (Hungr et
McDougall, 2009). Another numerical model is Mass Mov 2D that uses raster data as a basis for calculating mass conservation and mometum of materials during the event (Beguería et al., 2009). Many alternative models are still being developed for mass movement, such as Double layer-averaged two-phase flow model (Yu et al., 2019; Li et al., 2020; Shen et al., 2020), Smoothed-particle hydrodynamics (Lin et al., 2019), Unsupervised factor optimization (Sameen et al., 2020), DEM optimization (Ville et al., 2015; Sarma et al., 2020), Evaluation of raster resolution (Shirzadi et al., 2019; Wang et al., 2020), Spatial heterogeneity Model (Wang et al., 2020).

However, the main obstacle still persists, i.e. the difficulty of obtaining data in the field during the event due to security reasons. Therefore the purpose of this study is focused on identifying landslide processes, as one types of mass movements, from point of view of raster-based model. This would be important in providing one alternative solution to reconstruct landslide process for supporting disaster mitigation strategy, managing vulnerable communities and protecting critical environments.

\section{Methods}

\subsection{Measurement of topography and physical characteristics of landslide}

Rotational landslide in Malang Regency has been chosen as representative of mass movements. Landslide geometry was measured from fixed observation point in front of landslide. We used laser rangefinder for measuring vertical and horizontal 
distance (accuracy of $5 \mathrm{~cm}$ ) and azimuth (accuracy of $1^{\circ}$ ) to produce point cloud with $\mathrm{X}, \mathrm{Y}, \mathrm{Z}$ coordinates. This allowed us to measure the geometry of the landslide in detail and to produce Digital Surface Model as well.

Identification of soil physical properties was also carried out to determine the characteristics of landslide material. An outcrop of soil profile next to the landslide was investigated in order to have maximum similarity to the physical characteristics of landslide materials. Soil horizons and their boundaries were used to determine the position of slip surface.

\subsection{Dynamic raster-based model}

Data from topographic measurement and identification of physical characteristic of landslides werethen used as input for raster-based model. Mass Mov 2D algorithm was used by putting rheological parameters, viscosity, basal friction angle, internal friction, fluidization index and time. The output of the model was devoted to reconstruct the landslide process so that the mechanism of initiation, transportation and deposition of landslide materials could be identified.

\section{Results}

\subsection{Topography and physical characteristics of the landslide}

The studied landslide was located in Kemiri Village, Malang Regency, Indonesia. The type of mass movement was classified rotational landslide with a length of $78 \mathrm{~m}$ and a width of $27 \mathrm{~m}$ (Figure 1 and Figure 2). Landslide geometry was measured using a laser rangefinder to produce 116 filtered $\mathrm{X}$,
$\mathrm{Y}, \mathrm{Z}$ coordinates to eliminate improper coordinates other than Ground (classification value number 2 in the LiDAR data classification). These coordinates were combined into a simple point cloud to build the Digital Surface Model (DSM). Based on this DSM, the slope of the surrounding area was $36^{\circ}$ (or $72 \%$ ) with a slightly convex form.
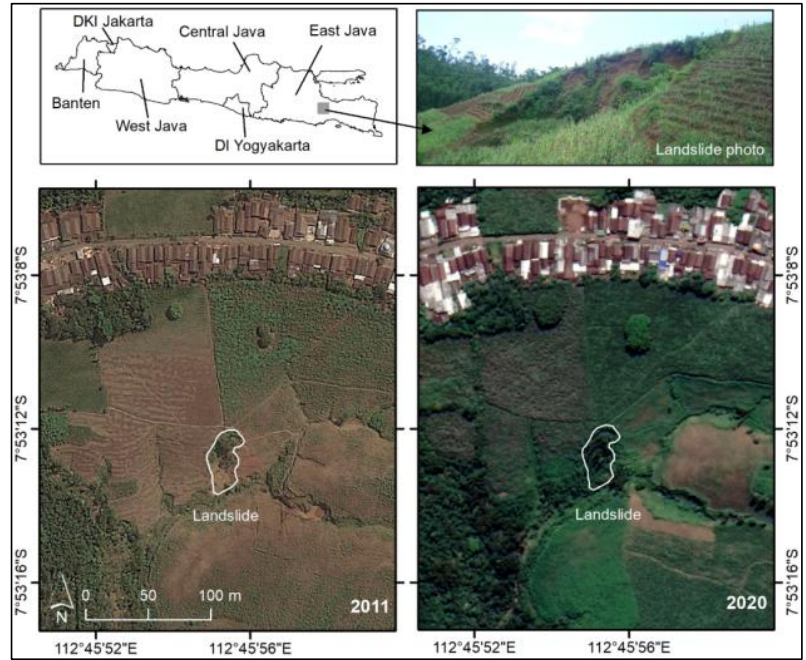

Fig. 1. Map of study area. Local population have reclaimed this landslide scar and turned it back into agriculture land. There is no new landslides recently.

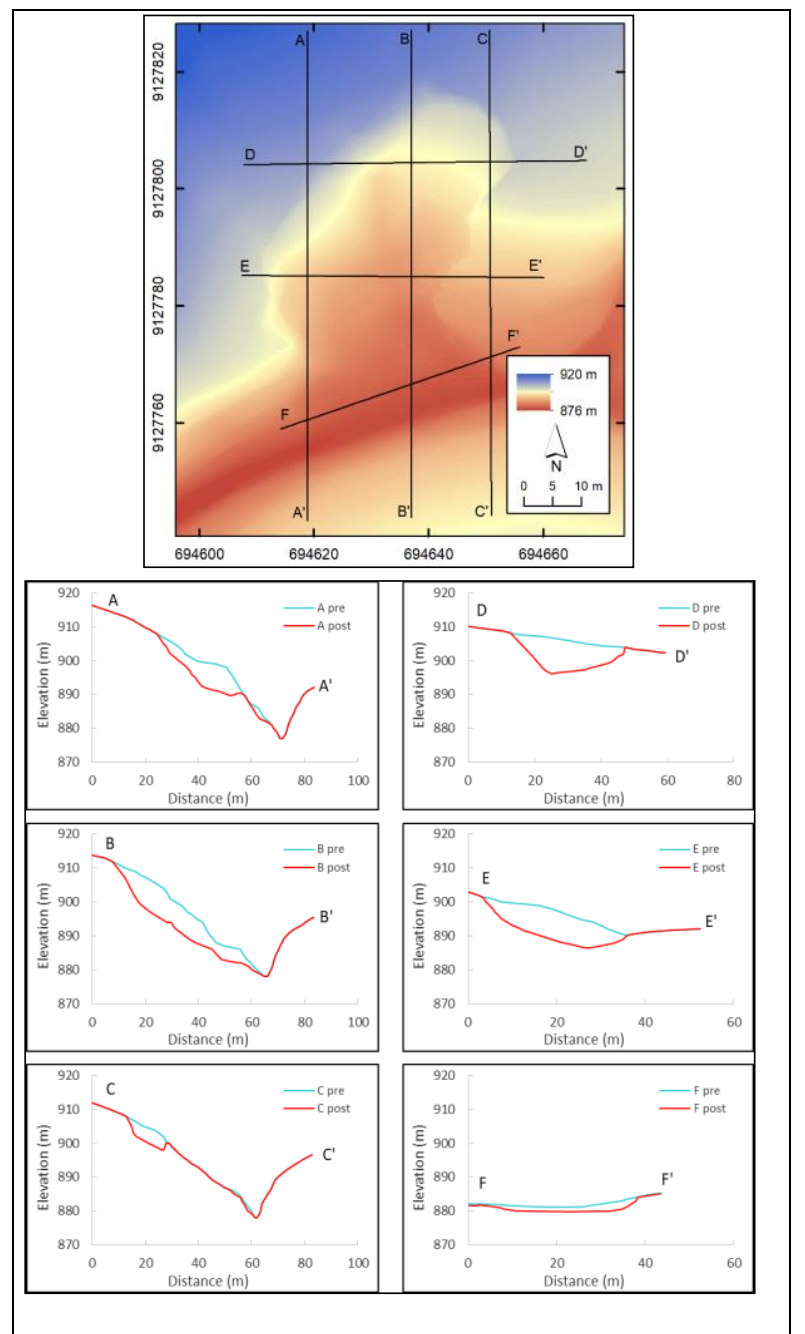

Fig. 2. Cross section of the landslide area showing topography before and after event. 
Soil in the study area was developed from weatheredquaternaryvolcanic parent materials from Gendis Mountains formation (Qpg). The soil types was classified as Alfisols, with brown topsoil (10 YR 4/3). The subsoil part including the endopedon had a dark brown color (10 YR 3/3). The soil texture was dominated by clay with lessivage/clay eluviation from topsoil to subsoil. The soil tended to be moistin field capacity condition. At depth of more than $228 \mathrm{~cm}$, weathered pumice deposits with a diameter of $10-20 \mathrm{~cm}$ existed.

The characteristics of landslide materials were closely related to the type of soil at the study site. Bingham's viscous rheological law was suitable for Alfisols with clay texture. i.e. rigid at low pressure, but can flow as thick fluid at high pressure. The friction between the landslide materials and the slip surface became smaller when it liquefied and reached saturation point, because the predominant soil texture in the soil profile was clay. Its particle densities ranged from 2110 to 2280 $\mathrm{kg} / \mathrm{m}^{3}$. Dynamic viscosity was high enough for clay soils because of its resistance to external forces. However, the transformation from solid to liquid phase was rapid, especially in the contact area between the toe of the landslide and the slip surface. This was aggravated by the position of landslide of which the toe touched directly a creek. The characteristics of landslide materials are generally summarized in Table 1 .

Table 1. Characteristics of landslide material used as input for rasterbased model

\begin{tabular}{lcc}
\hline \multicolumn{1}{c}{ Parameter } & Value & Unity \\
\hline Rheology model & Bingham viscous & - \\
Density & 2000 & $\mathrm{Kg} . \mathrm{m}-3$ \\
Yield stress & 70 & $\mathrm{~Pa}$ \\
Dinamic viscosity & 300 & $\mathrm{~Pa} . \mathrm{s}$ \\
Basal friction & 12 & $\circ$ \\
Internal friction & 14 & $\circ$ \\
Fluidization rate & 10 & $\mathrm{~m} . \mathrm{s}-1$ \\
Time & 100 & $\mathrm{~s}$ \\
\hline
\end{tabular}

3.2 Calculation of pixel values for dynamic raster-based model of landslides

Landslides were divided into pixels of $30 \times 30 \mathrm{~cm}$ in two raster dataset: DSM before and after the event. Based on cutand-fill analysis on these two DSM, the thickness of landslide materials was measured. DSM after the event expressed the elevation of slip surface as well.

The floating point values of each pixel represented the elevation of slip surface and the thickness of the landslide material. Determination of pixel value did not use the central point rule, but the largest share rule. It means the obtained pixel value is the most spatially dominant value within that pixel.

Changes in pixel values during the model run indicated the dynamics of mass movements. Cohesive landslide material moveddownward the slope with constant changes in properties during mass movement, which was represented by the rate of fluidization. Landslide materials moved because of the difference in potential values between pixels, from high to low. In every timestep (s), each pixel was always compared to its neighbors which had topology connection based on the direction of mass movement. The direction of the Energy Gradient Line (EGL) affected the direction of mass movement that can be devided into $\mathrm{X}$ and $\mathrm{Y}$ axes (Figure 3).

In general, movement of landslide materials went to the lower pixel. This movement wasaccompanied by the sedimentationof material along the movement. It allowed sedimentation of cohesive materialsto occur. This avoided anexcessive accumulation of landslide materials in one pixel (convergence). Weak stability of landslide material became the basis for performing repeated calculations (loops) until a stable condition is reached for every pixel.

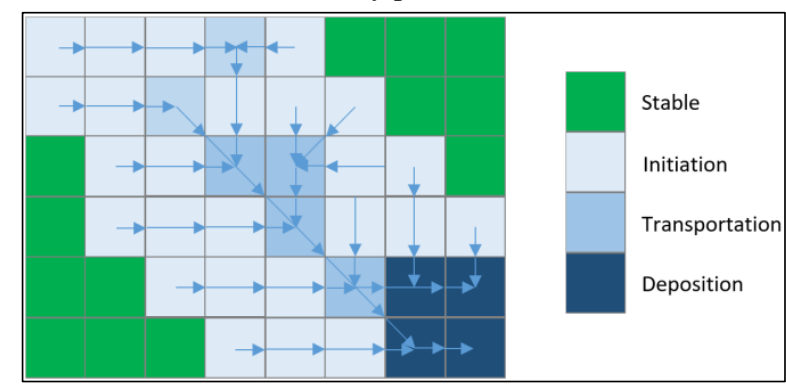

Fig. 3. Dynamics of spatial clasterization process of landslide material which produce spatial autocorrelation.

This raster-based model showed the dynamics of the landslide movement which was characterized by progressive erosion. The movement of landslide material started from the toe of landslide which decreased the stability of the landslide material of the landslide body. Consequently, this triggered movement on landslide body and followed by landslide crown.The mass movement of the landslide material was remarkably rapid at the beginning of the landslide, and slowed down during the sedimentation phase (Figure 4). Sedimentation of landslide material was accumulated at the bottom of the slope and clogged the creek underneath.

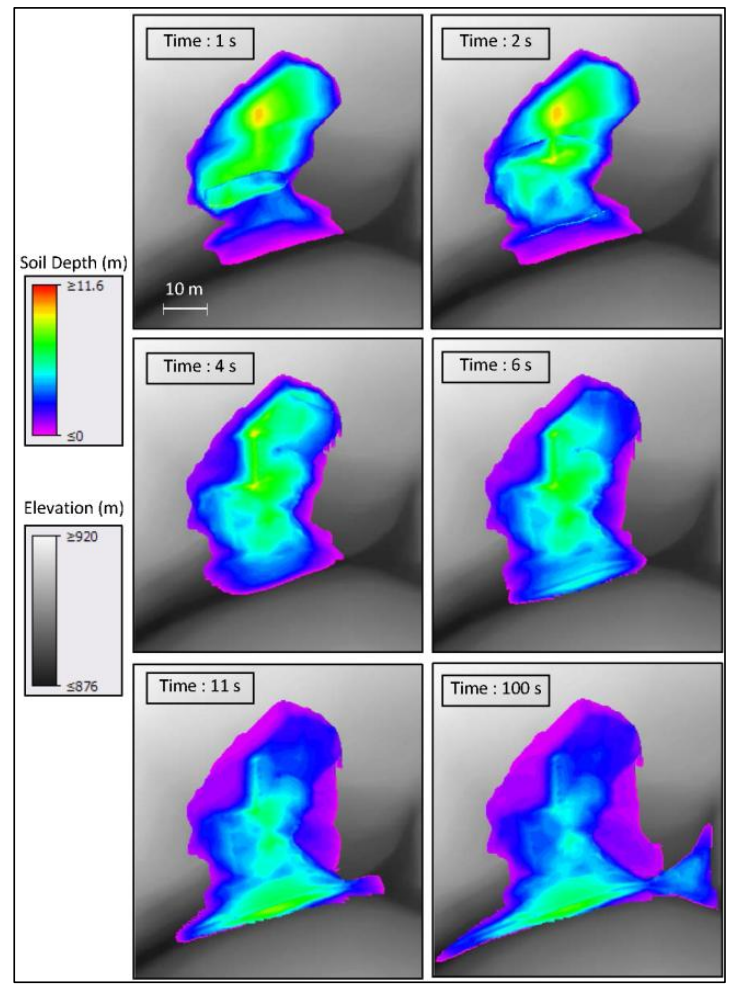

Fig. 4. Dynamic raster-based model of landslide materials

\section{Discussion}

The importance of Geo-Information Technology, affected to the fundamental needs of its development, both using technical approach and participatory approach (Wibowo and Nurani, 2019). This study shows that Geo-Information Technology, with its technical approach on spatial aspect, can 
also be applied for mass movement studies. Raster-based model allows to reconstruct mass movement in order to overcome common scientific issues, i.e. lack of direct observation during the real event due to security reasons.

Rotational landslides are one type of the most frequent mass movements (Wibowo et al., 2014; Wibowo et al., 2015; Gob et al., 2016; Cassel et al., 2018; Samodra et al., 2018), especially in tropical region such as in Indonesia (Wibowo, 2010). Given that rotational landslides often occur on complex terrain for which MassMov2D algorithm has been designed (Beguería et al., 2009), we decided to use it to build raster-based model.

Input data from point cloud that is acquired from laser measurement allows to build DSM and to measure the geometry of landslide. Laser measurement, both Laser Rangefinder and LiDAR, provides high-resolution topographic data and very helpful for fieldwork in a remote and dangerous area (Ville et al., 2015). Another input data is physical soil properties of the landslide material that is acquired from soil profile next to the landslide area. This is aimed to have maximum similarity to soil properties of the landslide material. Coupling between topographic data and physical soil properties of the landslide material is key parameter for dynamic raster-based model that we perform in this research.

The process of this rotational landslide on clay dominant alfisols can be reconstructed and identified thanks to dynamic raster-based model. Pixel values indicating elevation of landslide materials change over time. It means that landslide materials move dynamically during the event. The change of pixel values in the initiation process is much faster than in sedimentation process, showing that the movement of this landslide was extremely fast at the beginning $(7.35 \mathrm{~m} / \mathrm{s})$. It rapidly slowed down to $1.02 \mathrm{~m} / \mathrm{s}$ when the materials started to be deposited at foot slope. However, this velocity increased to $2.35 \mathrm{~m} / \mathrm{s}$ at time step $11 \mathrm{~s}$ when the abundant accumulation of this sedimented materials started to flow downstream following the topography of creek. This velocity progressively slowed down until it reached stable condition at timestep 100 $\mathrm{s}$. This phenomena is very common for subaerial mass movements on earth surface (Wibowo et al., 2015; Weidner et al., 2019; Marin and Velásquez, 2020; Chen et al. 2020).

The transfer mechanism of pixel value to neighbors follows the direction of EGL, indicating that landslide materials shift downward with continuous alternating process between erosion and sedimentation during the transport phase (Samodra et al., 2018). Wet clay soils like alfisols tend to be sticky, so that this cohesive materials are easily sedimented, except if there is enough force erode it during the rapid movement of landslide. However, this alternance disappears when the movement weakens at the landslide toe (Yu et al., 2019; Li et al., 2020; Shen et al., 2020). Absence of transfer of pixel value at timestep $100 \mathrm{~s}$ indicates that the dynamic raster-based model stops when sedimented landslide materials reach its stability condition at downslope.

The problematic of this research on lack of direct observation during the real event due to security reasons has been resolved, given that the raster-based model in this research is able to provide a detailed reconstruction and identification of mass movement process.

\section{Conclusion}

Dynamic raster-based modelfor mass movement using the MassMov2D algorithm allows to spatially reconstruct landslide in Malang Regency, Indonesia. This landslide reconstruction helps the identification of initiation, transport and deposition process of material of landslide from spatial point of view. This landslide process is depicted on the change in value of each pixel. The relationship between pixel and its neighbors is determined by the topology of the energy gradient line direction. It allowsto transfer values between each pixel. The dynamics of a landslide movement characterized by progressive erosion. The movement of landslide material started from the toeof landslide which decreased the stability of the landslide material of the landslide body. The output of this research would provide one alternative solution to reconstruct landslide process, even without direct observation during the real event due to security reasons. This kind of landslide reconstruction would be important for supporting disaster mitigation strategy, for managing vulnerable communities and for protecting critical environments.

\section{Acknowledgement}

This research was funded by Hibah Dosen Mandiri from Fakultas Geografi, UGM. The authors acknowledge Fibrian Tri Setyanto, Anung Aprian Feriadi and Dian HasimaIwan surya who were very helpful during the fieldwork. We also highly appreciate Sri Rahayu Utami, Ph.D., Dr. Sudarto, and Widianto, M.Sc. from Universitas Brawijaya, Malang for valuable discussion on soil studies. Laboratoire de Géographie Physique -CNRS UMR 8591, France was also very supportive by providing Laser Rangefinder (Trimble Laser Ace 1000) for this research.

\section{References}

Adamska-Szatko, M., Bała, J., 2010.Surface dynamic process simulation with the use of Cellular Automata. Acta Physica Polonica B Proceedings Supplement. 3 (2), p. 391-398.

Beguería, S., Van Asch, Th. W. J., Malet, J.-P., Gröndahl, S., 2009. A GIS-based numerical model for simulating the kinematics of mud and debris flows over complex terrain. Nat. Hazards Earth Syst. Sci., 9 (6), p. 1897-1909.

Bui, D.T., Tsangaratos, P., Nguyen, V.-T., Liem, N.V., Trinh P.T. 2020. Comparing the prediction performance of a Deep Learning Neural Network model with conventional machine learning models in landslide susceptibility assessment. Catena. 188, 104426. https://doi.org/10.1016/j.catena.2019.104426

Cassel, M., Piégay, H., Lavé, J., Vaudor, L., Hadmoko, D.S., Wibowo, S.B., Lavigne, F. 2018. Evaluating a 2D imagebased computerized approach for measuring riverine pebble roundness. Geomorphology. 311, 143-157. https://doi.org/10.1016/j.geomorph.2018.03.020

Chen, Z., Yang, P., Liu, H., Zhang, W., Wu, C. 2019. Characteristics analysis of granular landslide using shaking table model test. Soil Dynamics and Earthquake Engineering. 126, 105761. https://doi.org/10.1016/j.soildyn.2019.105761.

Dao, D.V., Jaafari, A., Bayat, M., Mafi-Gholami, D., Qi, C., Moayedi, H., Phong, T.V., Ly, H.-B., Le, T.T., Trinh, P.T., Luu, C., Quoc, N.K., Thanh, B.N., Pham, B.T. 2020. A spatially explicit deep learning neural network model for the prediction of landslide susceptibility. CATENA. 188 , https://doi.org/10.1016/j.catena.2019.104451

Gob, F., Gautier, E., Virmoux, C., Grancher, D., Tamisier, V., Primanda, K.W., Wibowo, S.B., Sarrazin, C., De Bélizal, E., Ville, A., Lavigne, F. 2016. River responses to the 2010 major eruption of the Merapi volcano, Central Java, Indonesia. Geomorphology, 273, $244 \quad-257$. https://doi.org/10.1016/j.geomorph.2016.08.025

He, Q., Shahabi, H., Shirzadi, A., Li, S., Chen, W., Wang, N., Chai, H., Bian, H., Ma, J., Chen, Y., Wang, X., Chapi, K., Ahmad, B.B. 2019. Landslide spatial modelling using novel bivariate statistical based Naïve Bayes, RBF Classifier, and RBF Network machine learning 
algorithms. Science of The Total Environment. 6631, 115. https://doi.org/10.1016/j.scitotenv.2019.01.329

Hungr, O., McDougall, S., 2009. Two numerical models for landslide dynamic analysis. Computers \& Geosciences. 35 (5), p. 978-992.

Katz, O., Aharonov, E., 2006.Landslides in vibrating sand-box : what controls types of slope-failure and frequency magnitude relations?. Earth and Planetary Science Letters. 247 (3-4), p. 280-294.

Li, J., Cao, Z., Cui, Y., Borthwick, A.G.L. 2020. Barrier lake formation due to landslide impacting a river: A numerical study using a double layer-averaged two-phase flow model. Applied Mathematical Modelling. 80, 574-601. https://doi.org/10.1016/j.apm.2019.11.031

Lin, C., Pastor, M., Li, T., Liu, X., Lin, C., Qi, H., Sheng, T. 2019. A PFE/IE - SPH joint approach to model landslides from initiation to propagation. Computers and Geotechnics. $114, \quad 103153$. https://doi.org/10.1016/j.compgeo.2019.103153

Marin, R.J., Velásquez, M. F. 2020. Influence of hydraulic properties on physically modelling slope stability and the definition of rainfall thresholds for shallow landslides. Geomorphology. 351 ,

106976. https://doi.org/10.1016/j.geomorph.2019.106976

Ran, Q., Hong, Y., Li, W., Gao J. 2018. A modelling study of rainfall-induced shallow landslide mechanisms under different rainfall characteristics. Journal of Hydrology. 563 , https://doi.org/10.1016/j.jhydrol.2018.06.040

790-801.

Sameen, M.I., Sarkar R., Pradhan B., Drukpa, D., Alamri, A.M., Park, H-J. 2020. Landslide spatial modelling using unsupervised factor optimisation and regularised greedy forests. Computers \& Geosciences. 134, 104336. https://doi.org/10.1016/j.cageo.2019.104336

Samodra, G., Hadmoko, D.S., Wicaksono, G.N., Adi, I.P., Yudinugroho, M., Wibowo, S.B., Suryatmojo, H., Purwanto, T.H., Widartono, B.S., Lavigne, F. 2018. The March 25 and 29, 2016 landslide-induced debris flow at Clapar, Banjarnegara, Central Java. Landslides. 15 (5), 985-993. https://doi.org/10.1007/s10346-018-0983-3

Sarma, C.P., Dey, A., Krishna A., M. 2020. Influence of digital elevation models on the simulation of rainfall-induced landslides in the hillslopes of Guwahati, India. Engineering Geology. 268, 105523. https://doi.org/10.1016/j.enggeo.2020.105523

Shen, W., Li, T., Li, P., Berti, M., Shen, Y., Guo, J. 2020. A two-layer numerical model for simulating the frontal plowing phenomenon of flow-like landslides. Engineering Geology. 2594, 105168 https://doi.org/10.1016/j.enggeo.2019.105168

Shirzadi, A., Solaimani, K., Roshan, M.H., Kavian, A., Chapi, K., Shahabi, H., Keesstra, S., Ahmad, B.B., Bui, D.T. 2019. Uncertainties of prediction accuracy in shallow landslide modeling: Sample size and raster resolution. CATENA. 178, 172-188. https://doi.org/10.1016/j.catena.2019.03.017

Wang, Y., Feng, L., Li, S., Ren, F., Du, Q., 2020. A hybrid model considering spatial heterogeneity for landslide susceptibility mapping in Zhejiang Province, China. Catena. 188, 104425. https://doi.org/10.1016/j.catena.2019.104425

Wang, S., Zhang, K., van Beek, L.P.H., Tian, X., Bogaard T.A. 2020. Physically-based landslide prediction over a large region: Scaling low-resolution hydrological model results for high-resolution slope stability assessment. Environmental Modelling \& Software. 124, 104607. https://doi.org/10.1016/j.envsoft.2019.104607

Weidner, L., DePrekel, K., Oommen, T., Vitton, S. 2019. Investigating large landslides along a river valley using combined physical, statistical, and hydrologic modeling. $\begin{array}{lll}\text { Engineering } & \text { Geology. } & 259,\end{array}$ https://doi.org/10.1016/j.enggeo.2019.105169

Ville A., Lavigne F., Virmoux C., Brunstein D., De Bélizal E., Wibowo S. B., Hadmoko D. S. 2015. Geomorphological evolution of the Gendol valley following the October 2010 eruption of Mt Merapi (Java, Indonesia), Géomorphologie : relief, processus, environnement, 21 (3), https://doi.org/10.4000/geomorphologie.11073

$235-250$

Wibowo, S.B.. 2010. Proposition d'un nouveau paramètre pour mesurer des glissements de terrain: la durée entre le point de saturation du sol et la rupture. Université Paris 1 Panthéon-Sorbonne. 73p.

Wibowo, S.B. 2010. Utilisation des classifications d'Oldeman et de Schmidt-Ferguson pour l'aptitude culturale des sols à Batu, Indonésie. In S. Khan, H.G.H Savenije, S. Demuth, P. Hubert (dir.). Hydrocomplexity: new tools for solving wicked water problems. IAHS publication, 338, 181-182

Wibowo S.B., Widianto, Sudarto. 2014. Influence of horizon boundary declivity toward duration of landslides generation on soil with medium and fine texture domination (in Indonesian). Jurnal Tanah dan Sumberdaya Lahan, 1 (1), 64-71

Wibowo, S.B., Lavigne, F., Mourot, P., Métaxian, J-P., Zeghdoudi, M., Virmoux, C., Sukatja, C.B, Hadmoko, D.S., Mutaqin, B.W. 2015. Coupling between Video and Seismic Data Analysis for the Study of Lahar Dynamics at Merapi Volcano, Indonesia. Géomorphologie : relief, processus, environnement. 21(3), 251-266. https://doi.org/10.4000/geomorphologie.11090

Wibowo S.B. 2016. Approches Multiscalaires de l'Érosion du Volcan Merapi, Indonésie: Contribution à la compréhension du déclenchement et de la dynamique des lahars. Université Paris 1 Panthéon-Sorbonne. 293p.

Wibowo, S.B., Nurani, I.W. 2019. Improving geoinformation technology by incorporating local participation.

Proceedings of SPIE - The International Society for Optical Engineering. 113110C. https://doi.org/10.1117/12.2550320

Yu, M.-L., Lee, C.-H. 2019. Multi-phase-flow modeling of underwater landslides on an inclined plane and consequently generated waves. Advances in Water Resources. 133, 103421. https://doi.org/10.1016/j.advwatres.2019.103421

(C) 2020 Journal of Geoscience, Engineering, Environment and Technology. All rights reserved. This is an open access article distributed under the terms of (http://creativecommons.org/licenses/by-sa/4.0/). 